\title{
Hypovitaminosis D in healthy children in Central Thailand: prevalence and risk factors
}

\author{
Kanit Reesukumal ${ }^{1}$, Kotchamol Manonukul ${ }^{1}$, Orathai Jirapongsananuruk², Wijittra Krobtrakulchai ${ }^{2}$, \\ Sithikan Hanyongyuth', Somruedee Chatsiricharoenkul ${ }^{3}$ and Busadee Pratumvinit ${ }^{1 *}$
}

\begin{abstract}
Background: There are limited data regarding the prevalence and risk factors relating to hypovitaminosis D in children of Thailand, a tropical country with abundant sunlight. The objective of this study was to assess the prevalence of hypovitaminosis $D$ and examine factors associated with hypovitaminosis $D$ in school-aged children in Bangkok, Thailand - a centrally located capital city.

Methods: This cross-sectional study evaluated 159 healthy children (33.3\% boys and 66.7\% girls), aged 6 to 12 years, in Bangkok, Thailand (located at $13.45^{\circ} \mathrm{N}$ ). Fasting plasma samples were examined for total 25 -hydroxyvitamin D $[25(\mathrm{OH}) \mathrm{D}]$ using electrochemiluminescence immunoassay. Demographic characteristics (age, sex, household income), past medical history (birth weight, allergic diseases, hospitalization), amount of sun exposure, anthropometric data, and selected biochemical tests were used to investigate for factors associated with hypovitaminosis D.

Results: Overall, the mean \pm SD level of plasma $25(\mathrm{OH}) \mathrm{D}$ was $64.0 \pm 15.1 \mathrm{nmol} / \mathrm{L}$. Hypovitaminosis $\mathrm{D}(<75 \mathrm{nmol} / \mathrm{L})$ was presented in $79.2 \%$ of subjects. Of these, the prevalence of vitamin $D$ insufficiency and vitamin $D$ deficiency were $59.7 \%$ and $19.5 \%$, respectively. In univariate analysis, children with hypovitaminosis $D(<75 \mathrm{nmol} / \mathrm{L})$ had a higher mean body mass index (BMI) percentile than the vitamin D-sufficient group (56.7 \pm 33.9 vs. $42.6 \pm 36.0$; $P$-value $=0.04$ ). Plasma PTH levels in the children with hypovitaminosis $D$ were significantly higher than in the children with normal levels of vitamin D $(4.34 \pm 1.38 \mathrm{vs} 3.78 \pm 1.25 \mathrm{pmol} / \mathrm{L} ; P$-value $=0.04)$. In multivariate analysis, high BMI percentile and high PTH concentration were the parameters associated with $25(\mathrm{OH}) \mathrm{D}$ level $<75 \mathrm{nmol} / \mathrm{L}$.

Conclusion: The prevalence of hypovitaminosis $D$ in healthy Thai children is very high, despite their exposure to sunlight, and that prevalence increases in children with a high BMI percentile. As a result, a formal recommendation for vitamin D supplementation in Thai children should be considered.
\end{abstract}

Keywords: 25-Hydroxyvitamin D, Hypovitaminosis D, Vitamin D insufficiency, Vitamin D deficiency, Children

\section{Background}

Vitamin D is important for calcium absorption from the gut and for promoting bone growth during childhood [1]. The most evident manifestation of vitamin D deficiency in infants and children is nutritional rickets [2]. Vitamin D receptors are present in most cells and tissues in the body, including osteoblasts, immune cells, $\beta$-islet cells, brain, heart, skin, gonads, prostate, colon, and breast [3]. Several studies have demonstrated the role of vitamin $\mathrm{D}$ in decreasing the risk of many chronic

\footnotetext{
* Correspondence: busadee.pra@mahidol.ac.th

'Department of Clinical Pathology, Faculty of Medicine Siriraj Hospital, Mahidol University, 2 Wang Lang Road, Bangkok Noi, Bangkok 10700, Thailand

Full list of author information is available at the end of the article
}

illnesses, including common cancers $[4,5]$, autoimmune diseases [6,7], infectious diseases [8,9], and cardiovascular diseases [10].

Vitamin D is absorbed from dietary food and produced by the skin during exposure to sunlight. People living near the equator who are exposed to sunlight without sun protection should have robust levels of 25-hydroxyvitamin D $[25(\mathrm{OH}) \mathrm{D}]$. However, recent studies have shown that hypovitaminosis D in children is very high, worldwide $[11,12]$. Yet, limited data are available regarding the vitamin D status of children living in Bangkok (geographically located at $13.45^{\circ} \mathrm{N}$ ), the capital of Thailand, where vitamin D supplements are not currently recommended 
and a vitamin D food fortification policy has not been implemented.

The aim of the present study was to evaluate the prevalence of hypovitaminosis D in Thai schoolchildren and investigate the factors associated with hypovitaminosis D. The results of this study may indicate the necessity of vitamin D supplementation for children in Thailand.

\section{Methods}

\section{Subjects}

This cross-sectional study was conducted amongst 1,268 children who attended a public primary school in Bangkok, Thailand. Bangkok is located at the latitude of $13^{\circ} 45^{\prime} \mathrm{N}$, a location that is, in part, characterized by abundant sunlight all year round. However, there are variations in ultraviolet (UV) irradiances in different months of the year. In Nakhon Pathom, which is located near Bangkok in the central part of Thailand, UV irradiances are highest in March or April, stable from May to September, lower from October to December, and then have an increasing trend from January to April [13].

Prior to commencing, this study was approved by the Siriraj Institutional Review Board. Written informed consent was obtained from all parents and written assent was obtained from all children.

Healthy children aged 6 to 12 years were enrolled between December 2011 and February 2012. Exclusion criteria were: liver or kidney diseases, malabsorptive disorders, previous surgery of gastrointestinal tract, tuberculosis, and use of steroids or anticonvulsants within the past 6 months. All participants or guardians completed questionnaires for the purpose of providing sociodemographic data, medical history, and amount of sun exposure. The amount of sun exposure was evaluated by two questions. One question inquired about the body part(s) exposed to the sun from 10 a.m. to 3 p.m. [14] without sun protections, such as sunscreen, umbrella, and/or clothing. The second question asked about estimated weekly sun exposure time. Body surface area was calculated using Lund and Browder chart [15].

A previous study regarding prevalence of hypovitaminosis D in Kuala Lumpur, Malaysia (latitude $3.09^{\circ} \mathrm{N}$ ), a country which is located near Thailand, revealed a prevalence of $72.4 \%$, when using the cut-off point of $\leq$ $50 \mathrm{nmol} / \mathrm{L}$ [16]. Using an estimated prevalence of $72 \%$ in Thai school children with a $7 \%$ margin of error, a total sample size of 158 school children was calculated for this study.

\section{Anthropometric measurements}

For anthropometric measurements, the participants wore light clothing and no shoes. Body weight and body composition (body fat, bone mass, and muscle mass) were measured during the same time period (between the hours of 7 a.m. and 10 a.m.) using Tanita BC-541 Inner Scan Body Composition Monitor (Tanita Corporation, Japan). Body weight was measured to the nearest $0.1 \mathrm{~kg}$. Body composition was measured using bioelectrical impedance analysis and body fat percentile was acquired from reference curves by McCarthy et al. [17]. Height was recorded to the nearest $0.1 \mathrm{~cm}$ using the Leicester Height Measure (Child Growth Foundation (CGF), London, England, UK). Each participant's body mass index percentile (BMI) was calculated using the Centers for Disease Control and Prevention BMI tool [18]. Waist and hip circumference were measured using a non-stretchable tape measure. Waist circumference was measured at the minimum circumference between the iliac crest and the rib cage. Hip circumference was measured at the maximum protuberance of the buttocks; the waist-hip ratio (WHR) was then calculated.

\section{Blood analysis}

Overnight fasting blood samples were collected from all participants between the hours of 7 a.m. and 10 a.m. during the month of February 2012. A team consisting of medical technologists to perform phlebotomy, researchers, and a physician was present during each patient blood sampling and anthropometric measurement session. A total of $10 \mathrm{~mL}$ venous blood was collected into two tubes: $3 \mathrm{ml}$ in an ethylenediaminetetraacetic acid (EDTA)-containing tube for the determination of intact parathyroid hormone (PTH) and total 25-hydroxyvitamin D $(25(\mathrm{OH}) \mathrm{D})$ concentrations and another $7 \mathrm{ml}$ in a tube containing lithium heparin for the analysis of calcium, phosphorus, magnesium, and albumin. Plasma parathyroid hormone $(\mathrm{PTH})$ and total $25(\mathrm{OH}) \mathrm{D}$ were analyzed using electrochemiluminescence immunoassay on Elecsys 2010 analyzers (Roche Diagnostics, Mannheim, Germany). Plasma calcium, phosphorus, magnesium, and albumin were analyzed using Modular P800 (Roche Diagnostics, Mannheim, Germany). The coefficients of variation (CVs) for $25(\mathrm{OH}) \mathrm{D}$ were $7.07 \%$ at a mean level of $40.3 \mathrm{nmol} / \mathrm{L}$ and $4.63 \%$ at a level of $84.5 \mathrm{nmol} / \mathrm{L}$. The CVs were $2.28 \%$ to $2.30 \%$ for $\mathrm{PTH}$ and $0.7 \%$ to $2.3 \%$ for albumin and cations. Total $25(\mathrm{OH}) \mathrm{D}$ was reported in nanomoles per liter $(\mathrm{nmol} / \mathrm{L})$ and the conversion factor to conventional unit $(\mathrm{ng} / \mathrm{mL}): 1 \mathrm{nmol} / \mathrm{L}=0.40 \mathrm{ng} / \mathrm{mL}$.

\section{Statistical analysis}

All analyses were performed using PASW v. 18.0 software (SPSS Inc, Chicago, IL, USA) and Microsoft Excel 2007 (Microsoft Corp, Redmond, WA). A two-sided $P$-value of 0.05 was considered to be statistically significant. Continuous variables are expressed as mean $\pm \mathrm{SD}$ or median (IQR). Categorical variables are expressed as proportions. The relationship between PTH and 25(OH)D 
concentration was assessed using Pearson's correlation coefficient. We used the Mann-Whitney $U$ test to compare the mean of the product of BSA with the duration of sunlight exposure per week (\% BSA $\times \mathrm{h} /$ week) values between BMI percentile groups ( $<85^{\text {th }}$ vs. $\geq 85^{\text {th }}$ percentile).

The following definitions for vitamin $\mathrm{D}$ status were used: vitamin D sufficiency, 25(OH)D level $\geq 75 \mathrm{nmol} / \mathrm{L}$; hypovitaminosis $\mathrm{D}, 25(\mathrm{OH}) \mathrm{D}$ level $<75 \mathrm{nmol} / \mathrm{L}$; vitamin D insufficiency, 25(OH)D level 50-74.9 nmol/L; and vitamin D deficiency; 25(OH)D level $<50 \mathrm{nmol} / \mathrm{L}[19,20]$. Multiple logistic regression analysis for factors associated with hypovitaminosis $\mathrm{D}(25(\mathrm{OH}) \mathrm{D}<75 \mathrm{nmol} / \mathrm{L})$ was performed using variables with a $P$-value $<0.2$ without multicollinearity in univariate analyses.

\section{Results}

One hundred and fifty-nine of 1,268 children with a mean age of $9.9 \pm 1.6$ years (age range: 6.5-12.8 years) participated in this cross-sectional study. There were 53 (33.3\%) boys and $106(66.7 \%)$ girls. The mean BMI percentile of participants was $53.7 \pm 34.7$. The mean $25(\mathrm{OH}) \mathrm{D}$ concentration for the entire group was $64.0 \pm 15.1 \mathrm{nmol} / \mathrm{L}$, ranging from 28.9 to $113.4 \mathrm{nmol} / \mathrm{L}$ (Figure 1).

Subjects in the six-year-old age group (6-6.9 year) had the highest proportion of vitamin D sufficient status $(42.8 \%)$ with a mean $25(\mathrm{OH}) \mathrm{D}$ concentration of $70.1 \mathrm{nmol} / \mathrm{L}$, while children in the eight-year-old age group (8-8.9 year) had the lowest proportion (9.1\%), with a mean $25(\mathrm{OH}) \mathrm{D}$ concentration of $59.5 \mathrm{nmol} / \mathrm{L}$. No trend in vitamin D status was found among the different age groups (Figure 2). Overall, hypovitaminosis D was found in 126 (79.2\%) subjects. Of these, 95

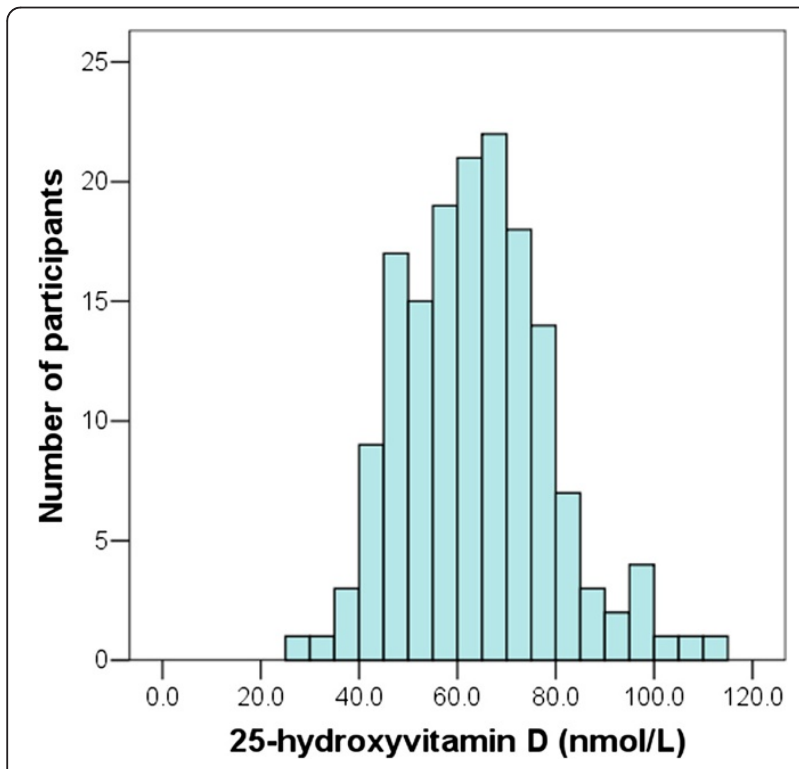

Figure 1 Distribution of plasma 25-hydroxyvitamin $D$ in healthy Thai school-aged children living in Central Thailand.
(59.7\%) had vitamin D insufficiency and 31 (19.5\%) had vitamin D deficiency. No subject had 25(OH)D level below $25 \mathrm{nmol} / \mathrm{L}$. Thirty-nine of fifty-three boys (73.6\%) had 25(OH)D levels lower than $75 \mathrm{nmol} / \mathrm{L}$ and $9(17.0 \%)$ of those had 25(OH)D level lower than $50 \mathrm{nmol} / \mathrm{L}$. Girls with 25(OH)D levels less than 75 and $50 \mathrm{nmol} / \mathrm{L}$ were 87 (82.1\%) and 22 (20.8\%), respectively. Vitamin D status was not significantly different between the two genders.

The mean PTH was $4.22 \pm 1.37$, ranging from 1.34 to $9.26 \mathrm{pmol} / \mathrm{L}$. Four $(2.52 \%)$ participants had elevated levels of PTH $(>6.89 \mathrm{pmol} / \mathrm{L})$. Hyperparathyroidism was found in $3.2 \%$ (3/95) of subjects with vitamin D insufficiency and $3.2 \%(1 / 31)$ of subjects with vitamin D deficiency. Mean corrected total calcium was $2.37 \pm$ $0.06 \mathrm{mmol} / \mathrm{L}$, with one $(0.63 \%)$ study participant having an elevated corrected calcium $(>2.5 \mathrm{mmol} / \mathrm{L})$. The median (IQR) duration of sun exposure was 4.00 (1.5-11.3) hours per week. The median (IQR) value of the product of BSA and duration of sunlight exposure per week (\% $\mathrm{BSA} \times \mathrm{h} /$ week) in overweight or obese subjects (BMI percentile $\geq 85^{\text {th }}, \mathrm{n}=32$ ) was not significantly different from that of healthy weight or underweight subjects (BMI percentile $\left.<85^{\text {th }}, \mathrm{n}=91\right)[133.8(15.6-283.8)$ vs. 88.5 (29.5-309.8) $\left.\mathrm{m}^{2} \mathrm{~h}, P=0.78\right]$.

In univariate analysis, hypovitaminosis $\mathrm{D}$ children had a higher mean BMI percentile than vitamin D-sufficient children $(56.7 \pm 33.9$ vs. $42.6 \pm 36.0 ; P$-value $=0.04)($ Table 1$)$. Waist circumference, body fat percentile, and muscle mass were higher in the hypovitaminosis D group; however, no statistically significant difference was observed $(P$-value $=0.07,0.10$, and 0.18, respectively $)$. Body fat percentage was higher in hypovitaminosis $\mathrm{D}$ children than normal vitamin $\mathrm{D}$ children $(18.6 \pm 8.81$ vs $14.8 \pm$ 8.95\%; $P$-value $=0.04)$. Children with hypovitaminosis $\mathrm{D}$ had higher mean PTH levels $(4.34 \pm 1.38$ vs. $3.78 \pm 1.25$ $\mathrm{pmol} / \mathrm{L} ; P$-value $=0.04)$; however and overall, plasma 25 $(\mathrm{OH}) \mathrm{D}$ and $\mathrm{PTH}$ were not found to be significantly correlated $(r=-0.12 ; P$-value $=0.13)$ (Figure 3$)$. Other factors, such as age, sex, household income, birth weight, medical history, sun exposure time, plasma calcium, phosphate, and magnesium were not different between children with hypovitaminosis D and vitamin D sufficiency (Table 1). In multivariate analysis, high BMI percentile $[\mathrm{OR}(95 \% \mathrm{CI})=1.03(1.01,1.06) ; P$-value $=0.01]$ and high PTH concentration $[\mathrm{OR}(95 \% \mathrm{CI})=1.69(1.06$, $2.68) ; P$-value $=0.03]$ were the variables associated with 25(OH)D level $<75 \mathrm{nmol} / \mathrm{L}$ (Table 2).

\section{Discussion}

This study evaluated the vitamin D status of healthy children in Bangkok, Thailand, which is located in the central region of the country. The findings of this study show that $79.2 \%$ of healthy schoolchildren between 6 to 12 years of age have hypovitaminosis $\mathrm{D}(<75 \mathrm{nmol} / \mathrm{L})$, 


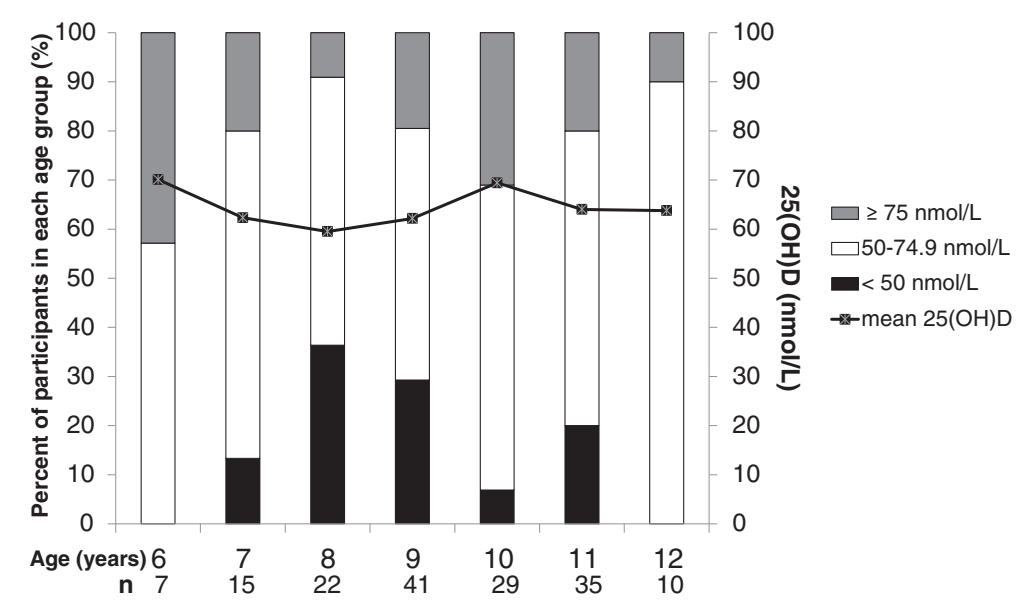

Figure 2 Concentration of 25-hydroxyvitamin $D$ by age.

with vitamin $\mathrm{D}$ insufficiency being observed in about two-thirds (59.7\%), and vitamin D deficiency occurring in about one-fifth (19.5\%). These results indicate that hypovitaminosis D occurs in people living at low latitude with almost year round sunlight, which is similar to other countries located in abundant sunshine areas $[21,22]$. Sunlight exposure is a major source of vitamin $\mathrm{D}$, but we were not able to predict vitamin D status from questionnaire questions relating to amount of sun exposure, which likely results from the questionnaire not being validated.

There are studies worldwide that show children with low vitamin D status, which range from 7-72\% (cut-off < $50 \mathrm{nmol} / \mathrm{L}$ ) and $26-98 \%$ (cut-off $<75 \mathrm{nmol} / \mathrm{L}$ ) [20]. This wide range of prevalence can result from variations between different research methods used, between different laboratories using the same method, as well as from different countries located in various latitudes. In tropical countries, school-aged children had prevalence rates of low vitamin D status of $56.6 \%, 28 \%$, and $68 \%$ in Colombia $\left(4^{\circ} \mathrm{N}, 5-12\right.$ yrs), Mexico $\left(19^{\circ} \mathrm{N}, 6-12\right.$ yrs), and Puerto Rico $\left(18.3^{\circ} \mathrm{N},<18 \mathrm{yrs}\right)$, respectively when using a cut-off value of $25(\mathrm{OH}) \mathrm{D}<75 \mathrm{nmol} / \mathrm{L}$ [23-25]. However, prevalence rates of $10 \%, 10 \%$, and $24 \%$ were shown when using a cut-off value of $25(\mathrm{OH}) \mathrm{D}<50 \mathrm{nmol} / \mathrm{L})$, respectively. In Malaysia $\left(3.09^{\circ} \mathrm{N}\right)$, the prevalence of low vitamin D status in children aged 7-12 years was very high (72.3\% by using a cut-off value of $<50 \mathrm{nmol} / \mathrm{L})$, as compared to other tropical countries [16]. Recent study of 6-12.9 year old healthy Thai children from four regions (i.e., central, north, northeast, and south) reported a prevalence of vitamin D deficiency of $52.2 \%$ in urban $(\mathrm{n}=101)$ and $29.2 \%$ in rural areas $(\mathrm{n}=217)$, using a cut-off value of $<50 \mathrm{nmol} / \mathrm{L}$; results which are higher than the results from our study [26]. Another study from Northeast Thailand found that $4 \%$ of school-aged children (6.0 to 14.0 yrs, $\mathrm{n}=529)$ had a serum 25(OH)D level below $50 \mathrm{nmol} / \mathrm{L}$, with boys having a statistically significantly higher serum 25(OH)D than girls [27]. Subjects from different parts of the country and the use of different vitamin $\mathrm{D}$ assays are possible explanations for the variations in these results. UV irradiance varies in different regions of Thailand, with the southern part recording the highest levels, the northern region the lowest, and the northeast and central regions occupying the middle level [13].

Other studies of various pediatric conditions in the same region of the country as our study have demonstrated that $71.2 \%$ of HIV-positive adolescents (12-20 yrs) and $64 \%$ of asthmatic children (6-18 yrs) had serum 25 (OH)D levels below $75 \mathrm{nmol} / \mathrm{L}$. Moreover, 24.7\% of HIVpositive adolescents and $19.2 \%$ of asthmatic children had serum 25(OH)D levels below $50 \mathrm{nmol} / \mathrm{L}$, findings which appear to be in a similar range as the findings in our study $[28,29]$. Another study in $\mathrm{HbE} / \beta$ thalassemia (5.9-14.1 yrs) found a higher prevalence of low vitamin $\mathrm{D}$ status when compared with other studies (patients with 25(OH)D levels below $50 \mathrm{nmol} / \mathrm{L}$ and $75 \mathrm{nmol} / \mathrm{L}$ were $23.9 \%$ and $90.0 \%$, respectively) [30].

The finding that children with hypovitaminosis D had a higher BMI percentile than those with a normal vitamin D status is consistent with previous studies that found lower 25(OH)D concentrations in higher BMI children [31-34]. In contrast, a recent study that was performed on younger children did not find the association between BMI and vitamin D status [35]. High BMI associated with vitamin D insufficiency is likely due to a higher body fat content. In our study, although the difference in body fat percentile in the hypovitaminosis D group and the normal vitamin $\mathrm{D}$ group was not significant, the body fat percentile tended to be higher in the hypovitaminosis D group. The potential mechanism of 
Table 1 Univariate analysis of investigated parameters, according to vitamin $D$ status $(n=159)$

\begin{tabular}{|c|c|c|c|c|c|c|}
\hline \multirow[t]{2}{*}{ Parameters } & \multicolumn{2}{|c|}{ Hypovitaminosis D (<75 nmol/L) } & \multicolumn{2}{|c|}{ Vitamin D sufficiency $(\geq 75 \mathrm{nmol} / \mathrm{L})$} & \multirow[t]{2}{*}{$P$-value } & \multirow{2}{*}{$\begin{array}{l}\text { Crude OR } \\
(95 \% \mathrm{Cl})\end{array}$} \\
\hline & $\mathrm{n}$ & Mean \pm SD or number $(\%)$ & $\mathrm{n}$ & Mean \pm SD or number $(\%)$ & & \\
\hline Age (years) & 126 & $9.86 \pm 1.54$ & 33 & $9.79 \pm 1.62$ & 0.82 & $1.03(0.81,1.32)$ \\
\hline Female sex & 126 & $87(69.0 \%)$ & 33 & $19(57.6 \%)$ & 0.22 & $1.64(0.75,3.61)$ \\
\hline Household income & 120 & & 31 & & & \\
\hline$\leq 20,000 \mathrm{THB} /$ month & & $52(43.3 \%)$ & & $15(48.4 \%)$ & 0.61 & 1 \\
\hline$>20,000 \mathrm{THB} /$ month & & $68(56.7 \%)$ & & $16(51.6 \%)$ & - & $1.23(0.56,2.71)$ \\
\hline Income(I):expense(E) & 94 & & 25 & & & \\
\hline $\mathrm{I}<\mathrm{E}$ & & $27(28.7 \%)$ & & $4(16 \%)$ & 0.54 & $1.52(0.40,5.78)$ \\
\hline$I \cong E$ & & $36(38.3 \%)$ & & $14(56 \%)$ & 0.30 & $0.58(0.21,1.62)$ \\
\hline$I>E$ & & $31(33 \%)$ & & $7(28 \%)$ & - & 1 \\
\hline Birth weight & 108 & & 28 & & & \\
\hline$<2.5$ kilograms & & $7(6.5 \%)$ & & $4(14.3 \%)$ & 0.19 & $0.42(0.11,1.54)$ \\
\hline$\geq 2.5$ kilograms & & $101(93.5 \%)$ & & $24(85.7 \%)$ & - & 1 \\
\hline Allergic diseases & 122 & $20(16.4 \%)$ & 32 & $4(12.5 \%)$ & 0.59 & $1.37(0.43,4.34)$ \\
\hline Hospitalization & 122 & $40(32.8 \%)$ & 31 & $7(22.6 \%)$ & 0.28 & $1.67(0.67,4.21)$ \\
\hline Feeding during the first & 120 & & 31 & & & \\
\hline \multicolumn{7}{|l|}{6 months } \\
\hline Breastfeeding only & & 39 (32.5\%) & & $7(22.6 \%)$ & - & 1 \\
\hline Infant formula only & & $11(9.2 \%)$ & & $5(16.1 \%)$ & 0.17 & $0.40(0.11,1.49)$ \\
\hline Combination & & $70(58.3 \%)$ & & $19(61.3 \%)$ & 0.39 & $0.66(0.26,1.71)$ \\
\hline \multicolumn{7}{|l|}{ Sun exposure } \\
\hline$\%$ BSA exposed $x$ & 94 & $238 \pm 388$ & 29 & $179 \pm 266$ & 0.45 & $1.00(0.999,1.002)$ \\
\hline \multicolumn{7}{|l|}{ hrs/wk } \\
\hline Hours/wk & 96 & $8.1 \pm 9.9$ & 29 & $6.5 \pm 8.0$ & 0.43 & $1.02(0.97,1.08)$ \\
\hline BMI percentile & 126 & $56.7 \pm 33.9$ & 33 & $42.6 \pm 36.0$ & 0.04 & $1.01(1.00,1.02)$ \\
\hline Waist circumference $(\mathrm{cm})$ & 126 & $66.3 \pm 11.5$ & 33 & $62.3 \pm 9.1$ & 0.07 & $1.04(0.997,1.08)$ \\
\hline Waist-to-hip ratio & 126 & & 33 & & & \\
\hline$<0.84$ & & $66(52.4 \%)$ & & $22(66.7 \%)$ & - & 1 \\
\hline$\geq 0.84$ & & $60(47.6 \%)$ & & $11(33.3 \%)$ & 0.15 & $1.82(0.81,4.06)$ \\
\hline Body fat percentile & 126 & $36.9 \pm 37.8$ & 33 & $24.7 \pm 36.0$ & 0.10 & $1.01(0.998,1.02)$ \\
\hline Bone mass (kg) & 117 & $1.45 \pm 0.59$ & 31 & $1.33 \pm 0.48$ & 0.29 & $1.47(0.72,3.04)$ \\
\hline Muscle mass (kg) & 117 & $28.2 \pm 7.27$ & 31 & $26.2 \pm 6.61$ & 0.18 & $1.04(0.98,1.11)$ \\
\hline Corrected calcium (mmol/L) & 125 & $2.37 \pm 0.06$ & 33 & $2.36 \pm 0.05$ & 0.73 & $3.06(0.01,1943)$ \\
\hline Phosphate (mmol/L) & 125 & $1.39 \pm 0.16$ & 33 & $1.40 \pm 0.14$ & 0.98 & $0.96(0.08,11.5)$ \\
\hline $\mathrm{Mg}(\mathrm{mmol} / \mathrm{L})$ & 125 & $0.85 \pm 0.05$ & 33 & $0.86 \pm 0.05$ & 0.42 & $0.04(0.01,122)$ \\
\hline PTH (pmol/L) & 126 & $4.34 \pm 1.38$ & 33 & $3.78 \pm 1.25$ & 0.04 & $1.40(1.02,1.94)$ \\
\hline Albumin (g/L) & 125 & $45.9 \pm 2.36$ & 33 & $45.9 \pm 2.37$ & 0.98 & $1.00(0.85,1.18)$ \\
\hline
\end{tabular}

low 25(OH)D concentration in high body fat subjects could be: 1) sequestration of vitamin $D$ by adipose tissue; 2 ) adipose tissue has both vitamin D receptors and 1- $\alpha$-hydroxylase enzymes, which can synthesize 1,25dihydroxyvitamin $\mathrm{D}$; and, 3) vitamin $\mathrm{D}$ may regulate adipose tissue mass, differentiation, and metabolism; consequently, low vitamin D status might contribute to obesity [36,37]. Another explanation could be that the obese subjects had less exposure to UV radiation [38]; however, we did not find a difference in sun exposure between subjects who were obese or overweight and subjects who were normal or underweight.

In this study, no differences in plasma levels of calcium and phosphate in these two groups of children 


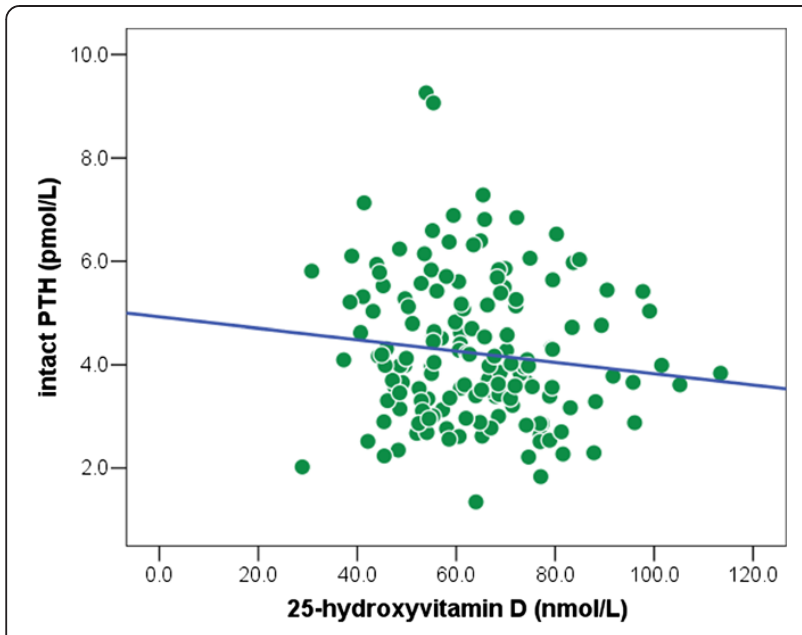

Figure 3 Relationship between plasma levels of intact PTH and 25 -hydroxyvitamin $D$ in school children $(n=159)$; Pearson $r=-0.12$, P-value $=0.13$.

were shown, but we found significantly higher PTH levels in children with hypovitaminosis $\mathrm{D}$, which was consistent with previous studies [39,40]. Although PTH levels are primarily regulated by ionized calcium and not directly by the level of vitamin D [39], it is well known that low 25(OH)D levels are associated with elevated PTH levels [41]. In addition, the estimation of optimal $25(\mathrm{OH}) \mathrm{D}$ concentration has been defined as the concentration that maximally suppresses the parathyroid hormone level [42].

This study has some inherent limitations. This was a single-center study that was undertaken in a limited geographical area - Bangkok, Thailand. The study participant sample reflects an unbalanced gender representation (predominantly females), which may not accurately represent or reflect the gender demographics of children in other

Table 2 Multivariate analysis of factors associated with plasma 25-hydroxyvitamin $D<75 \mathrm{nmol} / \mathrm{L}(\mathrm{n}=159)$

\begin{tabular}{llll}
\hline & B & Adjusted OR (95\% Cl) & P-value \\
\hline Birth weight & & & \\
$<2.5$ kilograms & -0.95 & $0.39(0.08,1.80)$ & 0.23 \\
$\geq 2.5$ kilograms & - & 1 & - \\
Feeding during the first & & & \\
6 months & & & - \\
Breastfeeding only & - & 1 & 0.07 \\
Infant formula only & -1.56 & $0.21(0.04,1.17)$ & 0.11 \\
Combination & -1.01 & $0.37(0.11,1.25)$ & 0.01 \\
BMI percentile & 0.03 & $1.03(1.01,1.06)$ & 0.75 \\
Body fat percentile & 0.00 & $1.00(0.97,1.02)$ & 0.15 \\
Muscle mass (kg) & -0.07 & $0.93(0.85,1.03)$ & 0.03 \\
PTH (pmol/L) & 0.52 & $1.69(1.06,2.68)$ & \\
\hline
\end{tabular}

areas of Thailand. Without long-term follow-up and additional larger studies it will be difficult to correlate the findings in this study with the onset and/or prevalence of other chronic diseases. We did not elucidate upon how vitamin $\mathrm{D}$ is acquired from diet for the following reasons: 1) only a limited amount of information regarding vitamin D content in Thai foods is available [26]; and, 2) a validated food frequency questionnaire and nutrient calculation program for vitamin $\mathrm{D}$ in Thai foods are also not currently available.

\section{Conclusions}

The prevalence of hypovitaminosis D in healthy children of Bangkok, Thailand is very high despite their exposure to sunlight. A recommendation for vitamin D supplementation and/or vitamin $\mathrm{D}$ fortification of foods should be considered for purposes of maintaining normal vitamin D status in schoolchildren, even in tropical countries like Thailand. Additional randomized clinical trials should be conducted to assess the role of vitamin $\mathrm{D}$ in extraskeletal outcomes.

\section{Competing interests}

The authors declare that they have no competing interests.

\section{Authors' contributions}

$K R, B P, K M, O J$, and SC discussed the original idea for this manuscript. $K R$, $B P$, WK and $\mathrm{SH}$ were responsible for the data collection. KR and BP analyzed the data and drafted the first version of the manuscript. All of the authors provided final approval.

\section{Acknowledgments}

The authors of this study would like to thank Chulaluk Komoltri, DrPH for assistance with statistical analysis and information management, Jutamas Thuvungkawath, BSc, Lamaiporn Langla, PhD, Sudcharee Kiartvich, MSc, Preechaya Wongkrajang, MD, and all staff of the Department of Clinical Pathology for their help in data collection. This study was supported by a grant from the Siriraj Research Development Fund, Grant Number (IO) R015432049. Research authors Kanit Reesukumal, Orathai Jirapongsananuruk, Somruedee Chatsiricharoenkul, and Busadee Pratumvinit each received a Chalermprakiat grant from the Faculty of Medicine Siriraj Hospital, Mahidol University.

\section{Author details}

'Department of Clinical Pathology, Faculty of Medicine Siriraj Hospital, Mahidol University, 2 Wang Lang Road, Bangkok Noi, Bangkok 10700, Thailand. ${ }^{2}$ Department of Pediatrics, Faculty of Medicine Siriraj Hospital, Mahidol University, Bangkok, Thailand. ${ }^{3}$ Department of Pharmacology, Faculty of Medicine Siriraj Hospital, Mahidol University, Bangkok, Thailand.

Received: 28 August 2014 Accepted: 26 February 2015 Published online: 14 March 2015

\section{References}

1. Gordon CM, DePeter KC, Feldman HA, Grace E, Emans SJ. Prevalence of vitamin D deficiency among healthy adolescents. Arch Pediatr Adolesc Med. 2004;158(6):531-7.

2. Basile LA, Taylor SN, Wagner CL, Quinones L, Hollis BW. Neonatal vitamin D status at birth at latitude 32 degrees 72 : evidence of deficiency. J Perinatol. 2007;27(9):568-71.

3. Misra M, Pacaud D, Petryk A, Collett-Solberg PF, Kappy M. Vitamin D deficiency in children and its management: review of current knowledge and recommendations. Pediatrics. 2008;122(2):398-417.

4. Grant WB. An ecologic study of dietary and solar ultraviolet-B links to breast carcinoma mortality rates. Cancer. 2002;94(1):272-81. 
5. Garland CF, Garland FC, Gorham ED, Lipkin M, Newmark H, Mohr SB. The role of vitamin D in cancer prevention. Am J Public Health. 2006;96(2):252-61.

6. Hypponen E, Laara E, Reunanen A, Jarvelin MR, Virtanen SM. Intake of vitamin $\mathrm{D}$ and risk of type 1 diabetes: a birth-cohort study. Lancet. 2001;358(9292):1500-3

7. Munger KL, Levin LI, Hollis BW, Howard NS, Ascherio A. Serum 25-hydroxyvitamin $D$ levels and risk of multiple sclerosis. JAMA. 2006:296(23):2832-8.

8. Ginde AA, Mansbach JM, Camargo Jr CA. Association between serum 25-hydroxyvitamin D level and upper respiratory tract infection in the Third National Health and Nutrition Examination Survey. Arch Intern Med. 2009;169(4):384-90.

9. Urashima M, Segawa T, Okazaki M, Kurihara M, Wada Y, Ida H. Randomized trial of vitamin D supplementation to prevent seasonal influenza A in schoolchildren. Am J Clin Nutr. 2010;91(5):1255-60.

10. Zittermann A. Vitamin D, and disease prevention with special reference to cardiovascular disease. Prog Biophys Mol Biol. 2006;92(1):39-48.

11. Holick MF. Resurrection of vitamin D deficiency and rickets. J Clin Invest. 2006;116(8):2062-72

12. Rovner AJ, O'Brien $\mathrm{KO}$. Hypovitaminosis D among healthy children in the United States: a review of the current evidence. Arch Pediatr Adolesc Med. 2008;162(6):513-9.

13. Janjai S, Kirdsiri K, Masiri I, Nunez M. An investigation of solar erythemal ultraviolet radiation in the tropics: a case study at four stations in Thailand. Int J Climatol. 2010;30(12):1893-903.

14. Holick MF. Vitamin D, deficiency. N Engl J Med. 2007;357(3):266-81.

15. Lund C, Browder N. The estimation of areas of burns. Surg Gynaecol Obstet. 1944;79:352-8

16. Khor GL, Chee WS, Shariff ZM, Poh BK, Arumugam M, Rahman JA, et al. High prevalence of vitamin D insufficiency and its association with BMI-for-age among primary school children in Kuala Lumpur, Malaysia. BMC Public Health. 2011;11:95.

17. McCarthy HD, Cole TJ, Fry T, Jebb SA, Prentice AM. Body fat reference curves for children. Int J Obes (Lond). 2006:30(4):598-602.

18. Centers for Disease Control and Prevention. Children's BMI Tool for Schools. http://www.cdc.gov/healthyweight/assessing/bmi/childrens_bmi/tool_for_ schools.html. Accessed 5 Jan 2015.

19. Holick MF, Binkley NC, Bischoff-Ferrari HA, Gordon CM, Hanley DA, Heaney $\mathrm{RP}$, et al. Evaluation, treatment, and prevention of vitamin D deficiency: an Endocrine Society clinical practice guideline. J Clin Endocrinol Metab. 2011;96(7):1911-30.

20. Palacios C, Gonzalez L. Is vitamin D deficiency a major global public health problem? J Steroid Biochem Mol Biol. 2014;144:138-45.

21. Sahu M, Bhatia V, Aggarwal A, Rawat V, Saxena P, Pandey A, et al. Vitamin D deficiency in rural girls and pregnant women despite abundant sunshine in northern India. Clin Endocrinol (Oxf). 2009;70(5):680-4.

22. Binkley N, Novotny R, Krueger D, Kawahara T, Daida YG, Lensmeyer G, et al. Low vitamin D status despite abundant sun exposure. J Clin Endocrinol Metab. 2007:92(6):2130-5.

23. Gilbert-Diamond D, Baylin A, Mora-Plazas M, Marin C, Arsenault JE, Hughes MD, et al. Vitamin D deficiency and anthropometric indicators of adiposity in school-age children: a prospective study. Am J Clin Nutr. 2010;92(6):1446-51.

24. Flores M, Macias N, Lozada A, Sanchez LM, Diaz E, Barquera S. Serum 25-hydroxyvitamin D levels among Mexican children ages 2 y to $12 \mathrm{y}$ : a national survey. Nutrition. 2013;29(5):802-4.

25. Suarez-Martinez EB, Perez CM, Cruz SK, Khorsandi S, Chardon C, Ferder L. Importance of vitamin D and vitamin D levels status in Puerto Ricans. J Health Care Poor Underserved. 2013;24(4 Suppl):38-47.

26. Rojroongwasinkul N, Kijboonchoo K, Wimonpeerapattana W, Purttiponthanee S, Yamborisut U, Boonpraderm A, et al. SEANUTS: the nutritional status and dietary intakes of 0.5-12-year-old Thai children. Br J Nutr. 2013;3(110 Supp):S36-44.

27. Houghton LA, Gray AR, Harper MJ, Winichagoon P, Pongcharoen T, Gowachirapant S, et al. Vitamin D Status among Thai School Children and the Association with 1,25-Dihydroxyvitamin D and Parathyroid Hormone Levels. PLoS One. 2014;9(8):e104825.

28. Chokephaibulkit K, Saksawad R, Bunupuradah T, Rungmaitree S, Phongsamart W, Lapphra K, et al. Prevalence of vitamin D deficiency among perinatally HIV-infected Thai adolescents receiving antiretroviral therapy. Pediatr Infect Dis J. 2013:32(11):1237-9.
29. Krobtrakulchai W, Praikanahok J, Visitsunthorn N, Vichyanond P, Manonukul K, Pratumvinit $B$, et al. The effect of vitamin d status on pediatric asthma at a university hospital. Thailand Allergy Asthma Immunol Res. 2013;5(5):289-94.

30. Nakavachara P, Viprakasit V. Children with hemoglobin E/beta-thalassemia have a high risk of being vitamin $D$ deficient even if they get abundant sun exposure: a study from Thailand. Pediatr Blood Cancer. 2013;60(10):1683-8.

31. Rockell JE, Green TJ, Skeaff CM, Whiting SJ, Taylor RW, Williams SM, et al. Season and ethnicity are determinants of serum 25-hydroxyvitamin D concentrations in New Zealand children aged 5-14 y. J Nutr. 2005;135(11):2602-8.

32. Absoud M, Cummins C, Lim MJ, Wassmer E, Shaw N. Prevalence and predictors of vitamin D insufficiency in children: a Great Britain population based study. PLoS One. 2011;6(7):e22179.

33. Alemzadeh R, Kichler J, Babar G, Calhoun M. Hypovitaminosis D in obese children and adolescents: relationship with adiposity, insulin sensitivity, ethnicity, and season. Metabolism. 2008;57(2):183-91.

34. Rodriguez-Rodriguez E, Navia-Lomban B, Lopez-Sobaler AM, Ortega RM. Associations between abdominal fat and body mass index on vitamin D status in a group of Spanish schoolchildren. Eur J Clin Nutr. 2010;64(5):461-7.

35. Zhou SJ, Skeaff M, Makrides M, Gibson R. Vitamin D status and its predictors among pre-school children in Adelaide. J Paediatr Child Health. 2014; doi: 10.1111/jpc.12770.

36. Earthman CP, Beckman LM, Masodkar K, Sibley SD. The link between obesity and low circulating 25-hydroxyvitamin D concentrations: considerations and implications. Int J Obes (Lond). 2012;36(3):387-96.

37. Wortsman J, Matsuoka LY, Chen TC, Lu Z, Holick MF. Decreased bioavailability of vitamin D in obesity. Am J Clin Nutr. 2000;72(3):690-3.

38. Konradsen S, Ag H, Lindberg F, Hexeberg S, Jorde R. Serum 1,25-dihydroxy vitamin $D$ is inversely associated with body mass index. Eur J Nutr. 2008;47(2):87-91.

39. Chung $\mathbb{H}$, Kim HJ, Chung S, Yoo EG. Vitamin D deficiency in Korean children: prevalence, risk factors, and the relationship with parathyroid hormone levels. Ann Pediatr Endocrinol Metab. 2014;19(2):86-90.

40. Cheng S, Tylavsky F, Kroger H, Karkkainen M, Lyytikainen A, Koistinen A, et al. Association of low 25-hydroxyvitamin D concentrations with elevated parathyroid hormone concentrations and low cortical bone density in early pubertal and prepubertal Finnish girls. Am J Clin Nutr. 2003;78(3):485-92.

41. Karaguzel G, Dilber B, Can G, Okten A, Deger O, Holick MF. Seasonal vitamin $D$ status of healthy schoolchildren and predictors of low vitamin D status. J Pediatr Gastroenterol Nutr. 2014;58(5):654-60.

42. Bischoff-Ferrari HA, Giovannucci E, Willett WC, Dietrich T, Dawson-Hughes B. Estimation of optimal serum concentrations of 25-hydroxyvitamin D for multiple health outcomes. Am J Clin Nutr. 2006;84(1):18-28.

\section{Submit your next manuscript to BioMed Central and take full advantage of:}

- Convenient online submission

- Thorough peer review

- No space constraints or color figure charges

- Immediate publication on acceptance

- Inclusion in PubMed, CAS, Scopus and Google Scholar

- Research which is freely available for redistribution 